\title{
Gender Equality Among CSR Managers and its Influence on Sustainable Development: A Comparison Among Italy, Spain and United Kingdom.
}

\author{
Armando Calabrese ${ }^{\text {a1 }}$, Roberta Costa a1, Nathan Levialdi Ghiron ${ }^{\text {a1 }}$, Tamara Menichini ${ }^{\text {b1* }}$
}

\begin{abstract}
The Sustainable Development Goals (SDGs) of the United Nations' 2030 Agenda for Sustainable Development are intended to orientate efforts of governments and companies to deal with environmental and social problems affecting contemporary societies. Gender Equality is one of these SDGs, and the women's participation in leadership at all levels of decision making in political, economic and public life, is one of its crucial targets. The paper analyses the progress in meeting this target with a focus on the European Union (EU) context. Particularly, a qualitative trend analysis is employed on the data from "World Bank Group" database, and the "Global 100: Most Sustainable Corporations in the World" for performing a comparison of the temporal evolution of Gender Equality in Italy, Spain and United Kingdom as countries registered in the "European Organizations of Sustainability Professions" portal. The results show that the mean female share of employment in senior and middle management is growing, and that managerial roles in CSR are a gender-virtuous field of management. Nevertheless, a question arises: is the gender equality among CSR managers an indicator of a sustainability-oriented approach to management? An analysis of Corporate Knights's ranking of the world's most sustainable corporations reveals that the female share of CSR managers is not directly linked to the presence of sustainable corporations. These empirical evidences arise some questions as well as some policy suggestions that will be discussed.
\end{abstract}

Keywords: Gender equality; Female leadership; Sustainable Development Goals (SDGs); Sustainable Development; Corporate Social Responsibility (CSR) Manager; Sustainability.

\section{Introduction}

The 17 United Nations Sustainable Development Goals (SDGs) highlight major requirements for human development and sensitize societies towards the achievement of new objectives that simultaneously have social, environmental and economic significance. A central milestone for the SDGs was the inclusion of the stand-alone SDG number 5, which is focused on the attainment of gender equality and women's rights at all levels of society. This stand-alone SDGs made gender equality and women's rights both something reachable and necessary to reach (Rosche, 2016). SDG number 5 aims to eradicate discrimination against women in both the public and private sectors, undertaking reforms to give equality of opportunity to women regarding their access to economic and natural resources, property and inheritance. In particular, SDG number 5 has to be achieved through focusing on detailed targets (9) referring to a series of

\footnotetext{
|*Corresponding author: Tamara Menichini. Email: tamara.menichni@unicusano.it

1 The authors contributed equally and are listed in alphabetical order

aDepartment of Enterprise Engineering, University of Rome "Tor Vergata", Via del Politecnico 1, 00133

Rome, Italy.

bIndustrial and Mechanical Engineering University of Rome "Niccolò Cusano" Via Don C. Gnocchi, 3.
} 
prerequisites of gender equality and women's rights, such as default of discrimination and violence against women, access to ownership rights and technology (Queisser, 2016). In order to turn SDG number 5 into real sustainable development, specific initiatives and not just statements of principle are required. Therefore, it is useful to investigate how organisations, especially those operating in the most economically advanced countries, are concretely reacting to the call of the SDG number 5. Despite much progress about women's rights and empowerment has been made, gender inequality is still an unresolved issue making the achievement of SDG number 5 a priority for all companies of OECD countries (Jütting et al., 2008). Particularly, the objective of Target 5.5 'Ensure women's full and effective participation and equal opportunities for leadership at all levels of decision making in political, economic and public life" (UN, 2017 a , p.9) represents one of the biggest gender gap all over the world. Failure to comply with the "Target 5.5" represents an important obstacle to the full empowerment of women and girls in the more advanced economies, hence such target should be prioritized for enactment (Rosche, 2016). This study aims at analysing the progress in meeting the target with a focus on a subset of OECD countries. Italy, Spain and United Kingdom were selected for this study, because they have organizations of professionals operating in the field of social responsibility and sustainability, which provide useful data for the analysis and are registered on the "European Organizations of Sustainability Professions" portal. Literature on board diversity and, in general, on management diversity has largely dealt with gender diversity. This has often been a topic of scientific debate because top-management decision-making is influenced by its gender composition (e.g. Bear et al 2010; Nielson and Huse, 2010). Indeed, female directors and female top-managers bring a different point of view to the board that can influence the decision-making process (Zelechowski and Bilimoria, 2004). Burke (2000) states that the female presence in top-management improves decision-making by enriching it with information, perspectives and debate. Other studies conclude that female directors are usually more objective and independent (Fondas 2000; Bilimoria and Wheeler 2000) and they are more likely to take decisions predicting negative consequences (Hillman, 2015). Finally, many studies determine that gender diversity positively influences financial performance (e.g. Low et al., 2015; Conyon and He, 2017), although other studies do not find any significant positive relationship between women presence on boards and financial performance (e.g. Velte, 2017). Gul et al. (2011) also recognize that board diversity is related to a better governance performance, more attention to innovation and creativity, thus ensuring a competitive advantage.

While there are many studies showing that gender diversity positively influences decision-making and financial performance, there still a few that have examined the impact of gender diversity on CSR performance (Rao and Tilt, 2016) and the association of gender diversity with corporate sustainability practices (Nadeem et al., 2017). This paper intends to examine whether the presence of female CSR managers can influence CSR performance, thus allowing companies to improve their corporate sustainability practices. Understanding this phenomenon is fundamental because the adoption of CSR practices has become a strategic factor of competitiveness, and companies are increasingly looking for ways to improve their CSR performance (Rao and Tilt, 2016). 
Based on the previous arguments, the authors proposed the following research question (RQ):

RQ1: is CSR is a gender-virtuous field of management?

RQ2: is the gender equality among CSR managers an indicator of a sustainability-oriented approach to management?

The rest of the paper is structured as follows. The next section synthesizes the existing literature used to pose our research questions. Section 3 describes data and data-sources. Section 4 presents evidence from the European context. Section 5 illustrates the discussion of results. Section 6 offers some concluding remarks.

\section{Literature Review}

Researches inquiring if having more women in the top-management leads to a better CSR performance are only recent. Velte's (2017) review of 200 previous scientific studies about the theme of women on board of directors reveals that it has a positive impact on CSR performance. Bear et al. (2010) sustain that women on board affect companies' CSR ratings and corporate reputation. Hyun et al. (2016) study a sample of 1500 indexed firms rated by Standard and Poor's Corporation (S\&P) in the period 20002009 finding that presence of women on board is positively related with firms' CSR ratings. Moreover, the strength of the positive correlation depends on the level of the firm's consumer market orientation.

Other studies associate female presence to a better CSR disclosure. Nalikka (2009) shows that women presence in boards determines a higher CSR disclosure. Also, Ben-Amar et al. (2017) point out on the fundamental role of women directors in CSR and in the disclosure of sustainability activities. Moreover, Boulouta (2013) inspects a sample of 126 companies of the S\&P 500 for a five-year period, determining that women directors enhance the credibility of CSR information by limiting CSR malpractice and making CSR reporting more relevant. Also, Liao et al. (2018) find that women directors improve credibility of CSR reporting by influencing decision-making toward assurance of CSR reports. Following this strand of research, Nekhili et al. (2017) study a sample of French listed companies belonging to the SBF 120 index from 2001 to 2011. The authors show that CSR reporting is more relevant in terms of market value when the presence of women in boards increases. Female directors enhance "credibility of the information disclosed, leading CSR reporting to be more economically viable in terms of higher firm value" (Nekhili et al., 2017, p. 82).

Further researches associate female presence in boards and top-management to CSR practices. In Italy, Baldarelli and Del Baldo (2016, p. 142) analyses two case studies to unveil the hidden role of women directors and women top-managers in promoting CSR and sustainability, in terms of "implementation of strategies, action and accountability tools, as well as in contributing to CSR resilience, producing innovation and overcoming social, ecological and economic challenges of disruptive markets". In Australia, Galbreath (2018) demonstrates that the women presence on boards is correlated to CSR practices leading to financial performance. The author finds that CSR fully mediates the link between number of female directors and financial performance. Also, Nadeem et al. (2017) find a significant positive correlation between women presence in Australian 
companies' boards and CSR practices in the period of 2010-2014, after Australian laws required that listed companies realised policies for increasing board diversity and CSR practices.

Another strand of research inquires the key role that female directors and female topmanagers play in the 'environmental decision-making'. In China, Wei et al. (2017) analyse a sample of quoted companies in the period 2008-2015, in order to evaluate the influence of female directors on corporate environmental investments. Their results show that there is a critical-mass effect: only when the number of women directors on boards reaches at least 3, they have a significantly positive impact on corporate environmental investments. However, the impact of the presence of female directors on environmental investments is conditioned by the companies' typology of ownership and industry. The effect is positive and significant only in the case of state-owned companies and companies from heavily-polluting industries. In Canada, Ben-Amar et al. (2017) study the effect of the presence of female directors on reporting about climate change-related risks on a sample of publicly listed Canadian firms over the period 2008-2014. The authors demonstrate that voluntary climate change disclosure increases with women percentage on boards, confirming also the critical mass theory with regard to board gender diversity. On the contrary, in Malaysia, Alazzani et al. (2017) find a positive correlation between presence of female directors on boards and social performance, but not with environmental performance. These authors conclude that female directors of Malaysian companies are more attentive to social issues than to environmental ones.

Finally, Mun and Jung (2017) analyse more than 800 Japanese companies in the period 2001-2009. The authors show that the presence of women in boards and managerial positions has increased in response to CSR normative, but also to ensure a good reputation with foreign institutional investors. In fact, the percentage of women in entry levels or non-managerial positions did not increase over the same period, pointing out that there was no real cultural change towards CSR and sustainability.

\section{Data Collection and Method}

To answer RQ1 and RQ2 data from different sources were collected. This section briefly describes each data source and illustrates how they has been used in the study for performing a qualitative trend analysis, i.e. an empirical approach for quantifying and observing evolutions of a variable over a period of time. Particularly, the dynamic of gender equality over time is captured by the values of a sequence of regularly spaced observations of homogeneous variables (i.e. percentage of female managers, percentage of female CSR managers and number of most sustainable corporations) considered at the same time intervals.

\section{1 "World Bank Group" Database}

In order to monitor gender equality among managers in the European context, data from the open access database of the "World Bank Group"1 were collected. The

\footnotetext{
${ }^{1}$ http://www.worldbank.org_Data collected are available at https://datacatalog.worldbank.org/dataset/sustainabledevelopment-goals
} 
database "World Bank Group", which contains a restructured version of the World Development Indicators (WDI), is aimed at supporting the monitoring of SDGs according to the goals and targets of the SDGs framework. The global indicator framework for SDGs, targets and indicators was adopted by the General Assembly on 6 July 2017 (UN, 2017). According to the aim of the present study, the relevant SDG is the "Goal 5: Achieve gender equality and empower all women and girls" (UN, 2017a, p.9). The relevant target is “Target 5.5: Ensure women's full and effective participation and equal opportunities for leadership at all levels of decision-making in political, economic and public life" (UN, 2017a, p.9). The relevant indicator is the "Indicator 5.5.2: Proportion of women in managerial positions" (UN, 2017a, p.10).

Following this lead, the WDI indicator selected for the analysis is the "Female share of employment in senior and middle management"2. For this indicator, the temporal coverage starts from the year 2004 to 2016 and all European countries are monitored. In particular, this paper analyses data from Italy (IT), Spain (ES) and United Kingdom (UK).

\subsection{European Organizations of Sustainability Professions Data}

Data on CSR professionals of the three aforementioned European countries were obtained consulting the European Association of Sustainability Professions (EASP) web portal ${ }^{3}$. These countries have an organization of professionals operating in the fields of social responsibility and sustainability. Recently, the Corporate Social Responsibility Association of Turkey (CSR Turkey) has become member of the European Sustainability Professionals Associations (EASP). However, no useful information about CSR members, has been founded on the CSR Turkey website 4 . For this reason, we excluded Turkey from the analysis. Also, the further EASP's member, VNU ${ }^{5}$ has been excluded from the analysis as no useful data has been founded.

Table 1 provides a brief description of activities, memberships and website link of each data source used in the study.

Table 1. CSR manager organizations, data and data sources.

\begin{tabular}{lllll} 
Network name & Description & Membership & Data source \\
\hline CSR manager & Italian national association for & Professionals operating & www.csrmanager \\
network & CSR professionals. Activities in private & large, & network.it \\
& regard: professional skills & medium, & small & \\
& development; promotion of enterprises, corporate & \\
& CSR manager profession; foundations and public & \\
& promotion of sustainability administration? & \\
& initiatives; & & \\
& interactions ${ }^{6}$. & & & \\
\hline
\end{tabular}

\footnotetext{
2 The indicator code is SL.EMP.SMGT.FE.ZS.

${ }^{3}$ https://www.europeanasp.eu

${ }^{4}$ www.csrturkey.org

${ }^{5}$ www.vnu-ev.de

${ }^{6}$ https://www.europeanasp.eu/membership/csr-manager-network.html

${ }^{7}$ https://www.europeanasp.eu/membership/csr-manager-network.html
} 


\begin{tabular}{|c|c|c|c|}
\hline $\begin{array}{l}\text { The Spanish } \\
\text { Association of } \\
\text { CSR } \\
\text { Professionals } \\
\text { (DIRSE) }\end{array}$ & $\begin{array}{l}\text { Founded in April 2013. Main } \\
\text { activities regard: mentoring; } \\
\text { training; } \\
\text { promotion of the creation of } \\
\text { Latin-American associations } \\
\text { of CSR professionals }{ }^{8} \text {. }\end{array}$ & $\begin{array}{l}\text { Only individuals: CSR } \\
\text { managers and high } \\
\text { directors of large and } \\
\text { medium size enterprise; } \\
\text { consultants, academics, } \\
\text { NGOs } 9\end{array}$ & www.dirse.es \\
\hline $\begin{array}{l}\text { ICRS } \\
\text { Institute of } \\
\text { Corporate } \\
\text { Responsibility } \\
\text { and } \\
\text { Sustainability }\end{array}$ & $\begin{array}{l}\text { UK's professional body for } \\
\text { sustainability professionals. } \\
\text { Main activities regard learning } \\
\text { opportunities and networking } \\
\text { for corporate responsibility } \\
\text { and } \\
\text { professionals }{ }^{10} \text {. }\end{array}$ & $\begin{array}{l}\text { Individuals and } \\
\text { Organisations } \\
\text { (corporates, SMEs, } \\
\text { charities, academic } \\
\text { institutions and not-for- } \\
\text { profits) }{ }^{11} \text {. }\end{array}$ & $\underline{\text { www.icrs.info }}$ \\
\hline
\end{tabular}

The female percentage of CSR managers in Italy and UK was calculated by looking for the names of female managers who are members of the CSR manager network and ICRS, as published on the websites (Table 1), and comparing their number with the total numbers of CSR managers belonging to the same country. The female percentage of CSR managers in Spain was directly derived from the DIRSE's website. In this case, no names of members are published.

\subsection{The Global 100: Most Sustainable Corporations in the World}

In order to analyse if CSR gender equality is an indicator of a sustainabilityoriented approach to management, data from the rank "The Global 100: Most Sustainable Corporations in the World"12 were analysed. The ranking is yearly published by Corporate Knights Inc. and it is based on a set of key performance indicators (KPIs) regarding leadership diversity, sustainability pay link, pension fund status, percentage of tax paid, and clean revenue. Data used for the ranking are derived from open data published by companies in their financial and sustainability reports.

\section{Results}

Figure 1 shows the "Female share of employment in senior and middle management" for Italy, Spain and United Kingdom. UK present the highest share of female presence for all the monitored years (from 2004 to 2016). The three trends present some differences. The Spanish share is growing, from the beginning to 2016. Instead, Italy and United Kingdom present a fluctuating trend of the women presence in senior and middle management. UK's results show a significant reduction among the years 2010 and 2011 while Italy presents a decreasing trend during the period 2007-2010 that could be related to the global financial crisis.

\footnotetext{
${ }^{8}$ https://www.europeanasp.eu/membership/dirse.html

${ }^{9}$ https://www.europeanasp.eu/membership/dirse.html

${ }^{10}$ https://www.europeanasp.eu/membership/icrs.html

11 https://www.europeanasp.eu/membership/icrs.html

12 http://www.corporateknights.com/reports/global-100/
} 


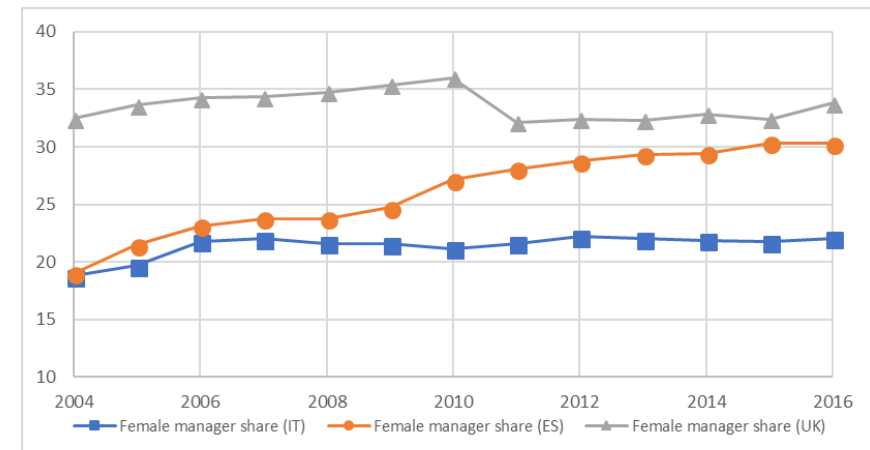

Figure 1. Female share of employment in senior and middle management (\%).

It is interesting to note how the mean value of "Female share of employment in senior and middle management" is growing starting from 2011 (Figure 2). Nevertheless, the percentage of women in managerial position is significantly lower than the male percentage. In the 2016 the female share is only of $32,06 \%$. The result is coherent with the recent data published by United Nations showing that "in the majority of the 67 countries with data from 2009 to 2015, fewer than a third of senior- and middlemanagement positions were held by women" (UN, 2017b, p.8).

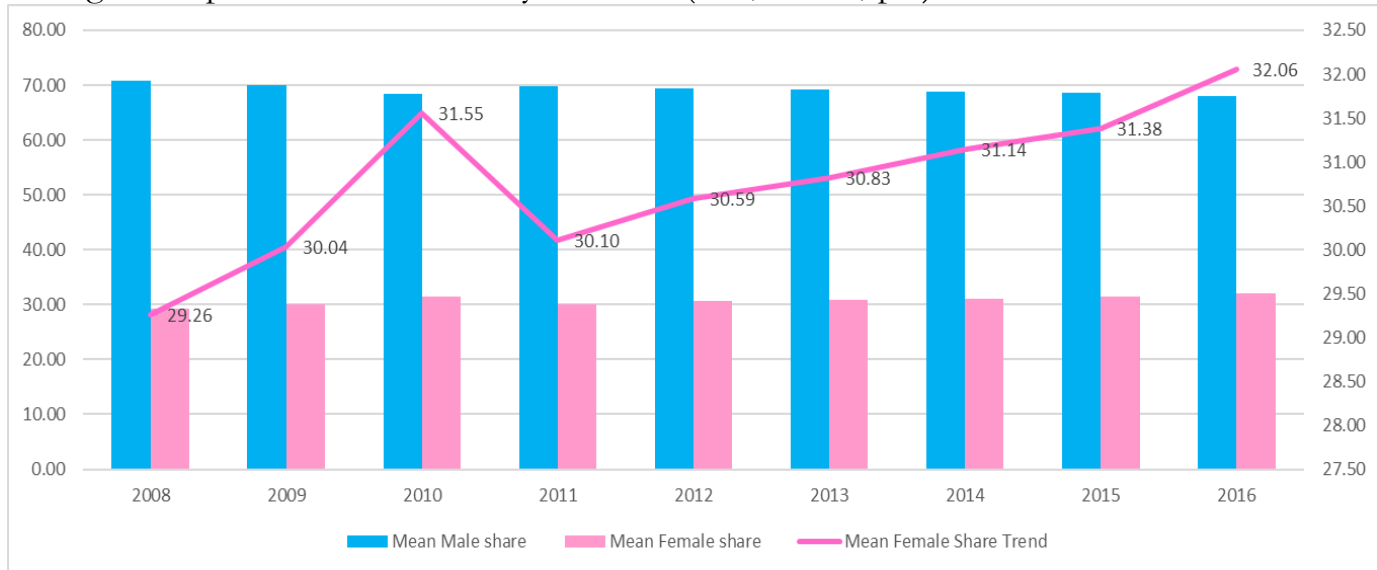

Figure 2. Female and male share of employment in senior and middle management (\%).

The "Female share of employment in senior and middle management" of Italy, Spain and United Kingdom for the years 2014, 2015, 2016 are compared to the female shares of CSR managers for the year 2018 (Figure 3). The results show that for Italy and Spain the presence of women in the social responsibility and sustainability fields of management is higher than those in the general field of management. The result is opposite for the United Kingdom. Italy presents the highest share of female CSR managers $(61,70 \%)$ followed by Spain $(54,11 \%)$ and finally the United Kingdom $(52,94 \%)$. Nevertheless, Italy presents the lowest percentage of "Female share of employment in senior and middle management" for all the three years under analysis $(21,90 \%$ in the $2014,21,75 \%$ in the 2015 and $22,04 \%$ in the 2016). Instead the United 
Kingdom presents the highest percentages (32,78\% in the 2014, 32,42\% in the 2015 and $33,81 \%$ in the 2016). The Spanish percentages are $29,42 \%$ in the $2014,30,35 \%$ in the 2015 and $30,31 \%$ in the 2016.

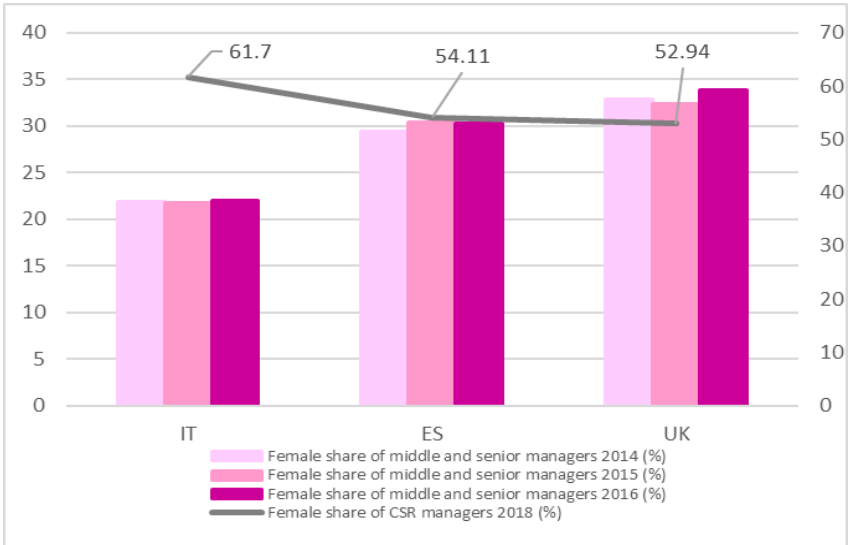

Figure 3. Female share of CSR managers 2018 compared to the female share of middle and senior managers of Italy (IT), Spain (ES) and United Kingdom (UK) for the years 2014, 2015 and 2016.

Furthermore, Figure 4 shows the number of the most sustainable corporations in Italy (IT), Spain (ES) and United Kingdom (UK), based on the analysis of the "The Global 100: Most Sustainable Corporations in the World" ranking provided by Corporate Knights Inc. For all the years under analysis (from 2014 to 2018) the United Kingdom has the highest number of sustainable companies while Italy has the lowest.

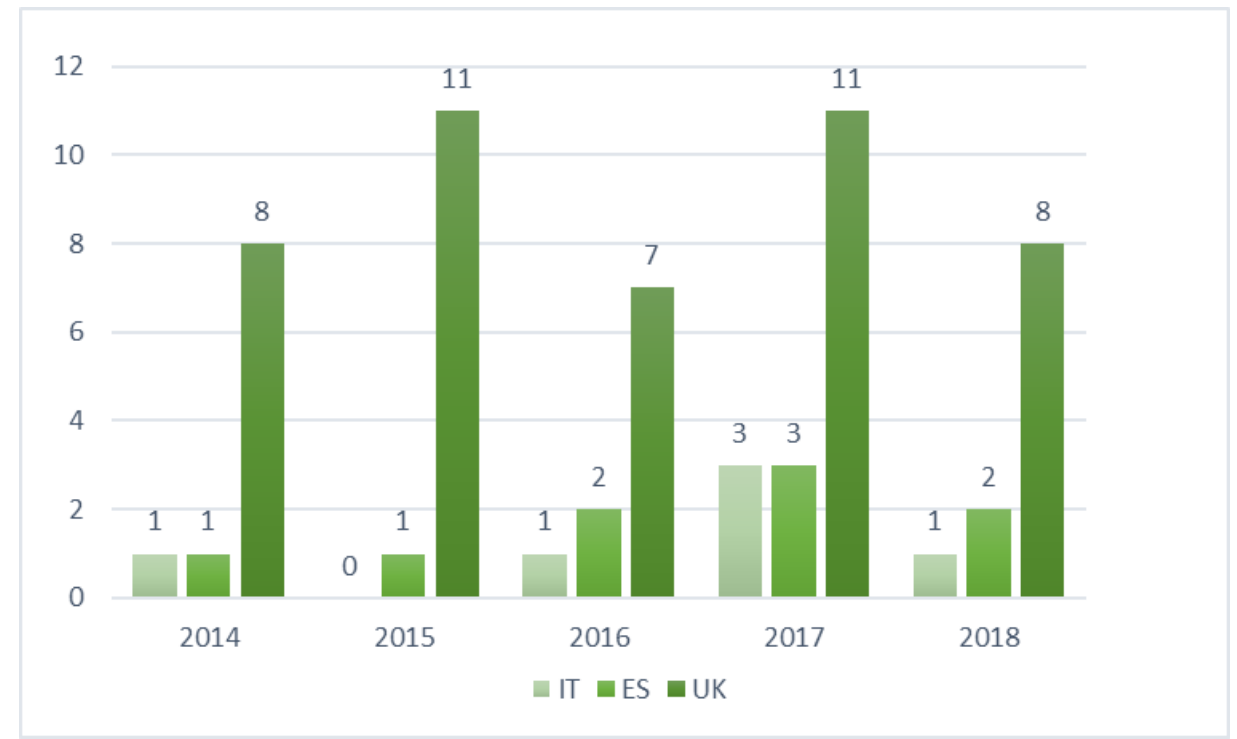

Figure 4. Number of the most sustainable corporations in Italy (IT), Spain (ES) and United Kingdom (UK). 
Table 2 shows the ranking of the three countries under study based on the $\mathrm{X}$ value and $\mathrm{Y}$ value. $\mathrm{X}$ values correspond to the female shares of CSR manager which are derived from the networks of sustainability professionals (Section 3.2). Y values correspond to the number of sustainable enterprises derived from the "The Global 100: Most Sustainable Corporations in the World" (Section 3.3). The ranking based on the X values shows that Italy is the best performer, followed by Spain then by the United Kingdom. However, Italy is the country with the lowest number of sustainable companies, for all the years under analysis. The trend is confirmed also for more recent years (2017 and 2018).

Table 2. Comparison among rankings of Italy, Spain and United Kingdom. X values are the female shares of CSR manager (\%); Y values correspond to the number of the "Global 100" most sustainable enterprises.

\begin{tabular}{|c|c|c|c|c|c|c|c|c|c|c|c|c|}
\hline & $\begin{array}{l}\text { X value } \\
2018\end{array}$ & $\begin{array}{l}X \text { rank } \\
2018\end{array}$ & $\begin{array}{l}\text { Y value } \\
2018\end{array}$ & $\begin{array}{l}\text { Y rank } \\
2018\end{array}$ & $\begin{array}{l}\text { Y value } \\
2017\end{array}$ & $\begin{array}{l}\text { Y rank } \\
2017\end{array}$ & $\begin{array}{l}\text { Y value } \\
2016\end{array}$ & $\begin{array}{l}\text { Y rank } \\
2016\end{array}$ & $\begin{array}{l}\text { Y value } \\
2015\end{array}$ & $\begin{array}{l}\text { Y rank } \\
2015\end{array}$ & $\begin{array}{l}\text { Y value } \\
2014\end{array}$ & $\begin{array}{l}\text { Y rank } \\
2014\end{array}$ \\
\hline IT & 0,6170 & 1 & 1 & 3 & 3 & 2 & 1 & 3 & 0 & 3 & 1 & 2 \\
\hline ES & 0,5411 & 2 & 2 & 2 & 3 & 2 & 3 & 2 & 1 & 2 & 1 & 2 \\
\hline UK & 0,5294 & 3 & 8 & 1 & 11 & 1 & 4 & 1 & 11 & 1 & 8 & 1 \\
\hline
\end{tabular}

\section{Discussion}

Some interesting results emerged from the study. First, considering data from Italy, Spain and United Kingdom, the mean share of female share of employment in senior and middle management is coherent with data provided by United Nations (UN, 2017). This confirms the validity of the WDI indicator used in the study for monitoring gender equality. The mean female share of managers is growing even though only about a third of senior and middle management positions was held by women in the period under analysis (from 2011 to 2016). Secondly, the analysis of female presence in the field of CSR management revealed that CSR is a gender-virtuous field of management (RQ1). In all the three countries under study the share of female CSR managers is higher than $50 \%$. In line with prior literature, the present study confirms that women mainly held positions in 'soft' managerial areas such as human resources, advertising and corporate social responsibility (e.g. Zelechowski and Bilimoria 2006).

Nevertheless, the comparison between the presence of female CSR manager and the presence of sustainable companies in the three countries revealed that gender equality among CSR managers is not a completely appropriate indicator of a sustainabilityoriented approach to management (RQ2). In fact, Italy presents the highest percentage of women among CSR managers but the lowest number of sustainable companies for all the years examined (from 2014 to 2018). While the United Kingdom presents the highest presence of sustainable companies and contemporarily the lowest share of female CSR managers. The obtained results are aligned with current literature stating that the evidence for a direct relation between women in managerial positions, financial performance, market value and environmental performance is weak (Alazzani et al., 2017; Galbreath, 2018, Nekhili et al., 2017; Wei et al., 2017). 
However, some studies regarding gender and CSR suggest that the female presence among directors exerts some influence on non-financial performance, in particular, on social performance and voluntarily reporting practice (Alazzani et al., 2017; Ben-Amar et al. (2017); Setó- Pamies, 2013). Given that women managers are mainly employed in the soft managerial areas, they can be more aware of soft managerial issues such as stakeholder interests and concerns (Daily and Dalton 2003). Therefore, women managers are more concerned about social issues influencing social responsiveness orientation of companies (Ibrahim and Angelidis, 1991). A female charismatic leadership "is able to promote cultural reorientation, valorize humanity, relationships and community, through the capability of "listening" and interpret needs and expectations, creating networks and leveraging collaborations among different actors" (Baldarelli and Del Baldo, 2016, p.148). In lights of these findings, policy makers are asked to promote the presence of women in business as source of potential benefits to society that go beyond improved company profitability; at the same time, researchers are asked to provide policy makers with meaningful investigations to inform gender equality decisions (Ferreira, 2015).

\section{Conclusions}

Gender diversity has attracted increasing interest from scholars and policy makers over the last decade. Nevertheless, there are still few studies that have examined the impact of gender diversity in managerial positions on CSR performance. This paper provides some evidence of the impact of gender equality in the field of social responsibility and sustainability management. First, the study analyses gender equality in the European context focusing on Italy, Spain and The United Kingdom. It is interesting to note how, the mean value of "Female share of employment in senior and middle management" is growing starting from 2011 even if only about a third of senior- and middle-management positions are held by women. These results confirm that gender equality in management is far from being achieved. A surprising result is obtained by the analysis of female presence in the field of CSR management that revealed CSR as a gender-virtuous field of management (RQ1). For all the analysed countries the female presence among CSR managers is more than half of the overall. Nevertheless, the comparison between the presence CSR female manager and the Global 100 ratings of sustainability revealed that the highest percentage of women is associated with the lowest presence of sustainable companies. Therefore, the gender equality among CSR managers, is not a completely appropriate indicator of a sustainability-oriented approach to management (RQ2).

The limitations of the study are primarily due to the small number of existing CSR manager organizations and networks which were used to derive data about gender diversity in the field of social responsibility and sustainability management.

The authors hope that the results shown in the paper stimulate further studies in the field of gender equality among CSR managers, and recommend future research to investigate how female leadership impacts on the company culture and contributes to the achievement of the sustainable development goals. 


\section{References}

Alazzani, A., Hassanein, A., \& Aljanadi, Y. (2017). Impact of gender diversity on social and environmental performance: evidence from Malaysia. Corporate Governance: The International Journal of Business in Society, 17(2), 266-283.

Baldarelli, M. G., \& Del Baldo, M. (2016). Ethics, gift and social innovation through CSR and female leadership in business administration in Italy. unf UmweltWirtschaftsForum, 24(2-3), 141-150.

Bear, S., Rahman, N. \& Post, C. (2010). The impact of board diversity and gender composition on corporate social responsibility and firm reputation. Journal of Business Ethics, 97(2), 207-21.

Ben-Amar, W., Chang, M., \& McIlkenny, P. (2017). Board gender diversity and corporate response to sustainability initiatives: evidence from the Carbon Disclosure Project. Journal of Business Ethics, 142(2), 369-383.

Bilimoria, D. \& Wheeler, J. V. (2000). Women corporate directors: Current research and future directions. In M. Davidson \& R. Burke (Eds.) Women in Management: Current Research Issues: 138-63. Dordrecht: Springer Science.

Boulouta, I. (2013). Hidden connections: The link between board gender diversity and corporate social performance. Journal of Business Ethics, 113(2), 185-197.

Burke, R. J. (2000). Women on corporate boards of directors: understanding the context. In R. J. Burke \& M. C. Mattis (Eds.) Women on Corporate Boards of Directors: International Challenges And Opportunities: 179-96. Dordrecht: Kluwer Academic Publishers.

Conyon, M. J., \& He, L. (2017). Firm performance and boardroom gender diversity: A quantile regression approach. Journal of Business Research, 79, 198-211.

Daily, C. M., \& Dalton, D. R. (2003). Women in the boardroom: A business imperative. Journal of Business strategy, 24(5). Galbreath, J. (2018). Is board gender diversity linked to financial performance? The mediating mechanism of CSR. Business \& Society, 57(5), 863-889.

Ferreira, D. (2015). Board diversity: Should we trust research to inform policy?. Corporate Governance: An International Review, 23(2), 108-111.

Fondas, N. (2000). Women on boards of directors: Gender bias or power threat. In R. J. Burke \& M. C. Mattis (Eds.) Women on Corporate Boards of Directors: International Challenges And Opportunities: 171-77. Dordrecht: Springer-Science.

Galbreath, J. (2018). Is board gender diversity linked to financial performance? The mediating mechanism of CSR. Business \& Society, 57(5), 863-889.

Giannarakis, G. (2014). Corporate governance and financial characteristic effects on the extent of corporate social responsibility disclosure. Social Responsibility Journal, 10(4), 569-590.

Gul, F. A., Srinidhi, B., \& Ng, A. C. (2011). Does board gender diversity improve the informativeness of stock prices?. Journal of Accounting and Economics, 51(3), 314-338.

Hillman, A. J. (2015). Board Diversity: Beginning to Unpeel the Onion. Corporate Governance: An International Review, 23(2), 104-07.

Hyun, E., Yang, D., Jung, H., \& Hong, K. (2016). Women on boards and corporate social responsibility. Sustainability, 8(4), 300.

Ibrahim, N., \& Angelidis, J. P. (1991). Effects of board members' gender on level of involvement in strategic management and corporate social responsiveness orientation. Proceedings of the Northeast Decision Sciences Institute, 208, 210.

Jütting, J. P., Morrisson, C., Dayton-Johnson, J., \& Drechsler*, D. (2008). Measuring gender (In) Equality: The OECD gender, institutions and development data base. Journal of Human Development, $9(1), 65-86$.

Liao, L., Lin, T. P., \& Zhang, Y. (2018). Corporate board and corporate social responsibility assurance: Evidence from China. Journal of Business Ethics, 150(1), 211-225.

Low, D. C., Roberts, H., \& Whiting, R. H. (2015). Board gender diversity and firm performance: Empirical evidence from Hong Kong, South Korea, Malaysia and Singapore. Pacific-Basin Finance Journal, $35,381-401$.

Mun, E., \& Jung, J. (2017). Change above the Glass Ceiling: Corporate Social Responsibility and Gender Diversity in Japanese Firms. Administrative Science Quarterly, 63(2), 409-440. 
Nadeem, M., Zaman, R., \& Saleem, I. (2017). Boardroom gender diversity and corporate sustainability practices: Evidence from Australian Securities Exchange listed firms. Journal of Cleaner Production, 149, 874-885.

Nalikka, A., (2009). Impact of gender diversity on voluntary disclosure in annual reports. Accounting and Taxation, 1 (1), 101-113.

Nekhili, M., Nagati, H., Chtioui, T., \& Nekhili, A. (2017). Gender-diverse board and the relevance of voluntary CSR reporting. International Review of Financial Analysis, 50, 81-100.

Nielsen, S. \& Huse, M. (2010). Women directors' contribution to board decision-making and strategic involvement: The role of equality perception. European Management Review, 7(1), 16-29.

Queisser, M. (2016). Gender equality and the sustainable development goals. OECD Insights, 87-90.

Rao, K., \& Tilt, C. (2016). Board composition and corporate social responsibility: The role of diversity, gender, strategy and decision making. Journal of Business Ethics, 138(2), 327-347.

Rosche, D. (2016). Agenda 2030 and the Sustainable Development Goals: gender equality at last? An Oxfam perspective, Gender \& Development, 24(1), 111-126.

Setó-Pamies, D. (2015). The relationship between women directors and corporate social responsibility. Corporate Social Responsibility and Environmental Management, 22(6), 334-345.

UN-United Nations (2017a). General Assembly Resolution. Global Indicator Framework for The Sustainable Develoment Goals and Targets of the 2013 Agenda for Sustainable Development. Available at: https://undocs.org/A/RES/71/313 (Accessed on June 2018).

UN-United Nations (2017b). Progress towards the Sustainable Development Goals. Available at:

http://www.un.org/ga/search/view doc.asp?symbol=E/2017/66\&Lang=E (Accessed on June 2018).

Velte, P. (2017). Do women on board of directors have an impact on corporate governance quality and firm performance? A literature review. International Journal of Sustainable Strategic Management, 5(4), 302-346.

Wei, F., Ding, B., \& Kong, Y. (2017). Female Directors and Corporate Social Responsibility: Evidence from the Environmental Investment of Chinese Listed Companies. Sustainability, 9(12), 2292.

Zelechowski, D. D., \& Bilimoria, D. (2006). Characteristics of CEOs and Corporate Boards with Women Inside Directors. Corporate Board: Role, Duties \& Composition, 2(2). 